\title{
Students' Perception about Teachers' Nonverbal Immediacy Behavior: A Case of Communication Sciences Faculty
}

\author{
Mestan Küçük, Anadolu University, Turkey
}

\begin{abstract}
Few concepts in instructional communication literature have received as much attention as teacher immediacy. Although it is very intensively researched in foreign literature, there are small amount of research in Turkey about in class communication especially nonverbal immediacy behaviors. The purpose of this study is to determine how communication students' evaluate their lecturers' nonverbal immediacy behaviors. Nonverbal Immediacy Scale (NIS), which was developed by Richmond, McCroskey, and Johnson (2003) were used to collect data. The NIS was applied to 185 college of communication students from a University located in the Central Anatolia Region of Turkey. Results indicate that colleges of communication students are finding adequate teachers' nonverbal immediacy behaviors and there are no differences between males and females level of perception.
\end{abstract}

\section{Introduction}

Whether we realize or not interpersonal communication takes very important place in our lives. Interpersonal communication is the communication we use when engaged in face-toface setting with one or more other people. While there are many definitions available, interpersonal communication is often defined as the communication that takes place between people who are interdependent and have some knowledge of each other. Interpersonal communication includes what takes place between a son and his father, an employer and an employee, two sisters, a teacher and a student, two lovers, two friends, and so on.

\section{The Teacher-student Communication As an Interpersonal Communication}

The teacher-student relationship, while unique, shares several similarities with other interpersonal relationships. Despite two differences in the teacher-student relationship are that it lacks the equality typically associated with friendship and has time constraints not typical of friendship, Frymeir and Houser (2000, s. 208) says that they don't affect the basic functioning of communication in relationship development and maintenance. Teachers and students go through a process of meeting one another, exchanging information, and adjusting 
and developing expectations similar to what any two individuals would go through in developing a relationship. Both teachers and students have goals they wish to achieve. The achievement of those goals depends on the teacher and student's ability to negotiate with one another and resolve conflict. These are communication intensive activities that go on all interpersonal relationships.

As an interpersonal communication, the teacher and student communication have very important place in educational settings. Historically, instructional communication scholars have focused their research on explicating instructor characteristics and behaviors and student traits and dispositions that contribute to classroom outcomes. The past thirty years of research on instructional communication, has identified several interpersonal variables that are positively related to learning. Variables such as immediacy, communicator style, selfdisclosure, solidarity, humor, caring and compliance-gaining have contributed to understanding of the dynamic student-teacher relationship and how it result in student learning (Frymeir, \& Houser, 2000). That is embedded within this body of research is the implicit idea that instructor can communicate with their students in ways that either enhance or inhibit what student bring the classroom interactions that contribute to learning (Witt, Schrodt, Wheeless, \& Bryand 2014).

Interpersonal perceptions and communicative relationships between teachers and student are crucial to the teaching and learning process, and the degree of immediacy between teacher and student is an important variable in those relationships. Immediacy behaviors have been primarily used to describe and understand the teacher-student relationship.

\section{Verbal and Nonverbal Immediacy}

Immediacy is a perception of closeness between persons was first advanced by Mehrabian (1969) and adapted to the classroom by Andersen (1979). Richmond (2002) defines immediacy as "the degree of perceived physical or psychological closeness between people" (p. 68). Immediacy is a communication behavior and involves verbal and nonverbal elements. There are substantial amount of research has related it to effective teaching and to an increase in students' motivation (See McCroskey et al., 2005). 
Verbal teacher immediacy refers to verbal messages that show empathy, openness, kindness, reward, praise, feelings of inclusiveness, humor, personal knowledge and willingness to engage students in communication, among others. Inevitably linked to nonverbal immediacy behaviors, verbal immediacy has been associated with increased cognitive and affective learning and with increased motivation (Gorham, 1988; Cristophel, 1990; Plax, Kearny, McCroskey, \& Richmond, 1986; Richmond, McCroskey, Kearny, \& Plax, 1987; Rodríguez, Plax, \& and Kearny, 1996).

What we say is an important way of getting our message across but using our voice is only the tip of the iceberg. We actually communicate more information using nonverbal signals, gestures, facial expression, body language even our appearance. Recognizing that nonverbal messages typically provide the framework for interpreting verbal messages, teacher nonverbal behavior in the classroom may well provide the context for students' interpretations of those verbal messages teacher employ. This nonverbal signals-nonverbal immediacy behaviors- can give clues and additional information and meaning over and above verbal communication.

"Nonverbal immediacy may exist independently of verbal messages and this is why it is often given more importance in classroom research" (Ballester, 2015, p.11). Nonverbal teacher immediacy refers to nonverbal behaviors that induce physical and emotional closeness, which in turn increase students' affect towards the teacher, the course and the content (Richmond, \& McCroskey, 2000). Nonverbal immediacy consist of behaviors such as smiling at students, making eye contact, moving around the classroom, and using vocal variety. Similarly to verbal immediacy, perceptions of nonverbal immediacy have been shown to increase affective, cognitive and behavioral learning, motivation and perceptions of clarity and credibility (Richmond, Gorham, \& McCroskey, 1987; Pogue \& AhYun, 2006; Hsu, 2010).

Briefly we can say that by communicating through immediate behaviors, teachers establish a positive relationship with students and create a positive environment in class, which translates as students being more interested and motivated and learning more effectively.

Although it is very intensively researched in foreign literature, there are small amount of research in Turkey about in class communication (Akkuzu, \& Akkaya 2014; Argon, \& Zafer 2009; Başaran, \& Erdem 2009; Çetinkanat, 1997; Hazneci 2012; Karagöz, \& Kösterelioğlu 2008; Tarhan 2000), especially nonverbal immediacy behaviors. For this reason in this study 
researcher wonder that what is the situation in a Communication Science Faculty that is in the University located in the Central Anatolia Region of Turkey. How communication students' evaluate their lecturers' nonverbal immediacy behaviors?

\section{Methodology}

This study utilized a descriptive research design. In view of the descriptive nature of the case, just quantitative data were collected. To establish the conceptual framework of the study, a survey research, were conducted. A survey method is directed toward determining the students' evaluation about teachers' nonverbal immediacy behavior.

\section{Measures}

Nonverbal Immediacy Scale (NIS), which was developed by Richmond, McCroskey, and Johnson (2003) were used to collect data. It consists of 26 Likert type items (13 positively worded, 13 negatively worded). Scale adapted into Turkish Language by Küçük and İspir (2016). Results from exploratory and two step-confirmatory factor analyses demonstrated that the original form of NIS and its Turkish version were consistent in terms of hypothesized structure. Internal consistency reliabilities measured as Cronbach's alpha coefficients and it is found .94 .

\section{Participants}

The NIS was applied to 185 colleges of communication students from a University located in the Central Anatolia Region of Turkey.

Table 1. Participants

\begin{tabular}{llll}
\hline & Frequency & Percent & $\begin{array}{l}\text { Cumulative } \\
\text { Percent }\end{array}$ \\
\hline Male & 107 & 57,8 & 57,8 \\
Female & 76 & 41,1 & 98,9 \\
Missing & 2 & 1,1 & 100 \\
\hline Total & 185 & 100 & \\
\hline
\end{tabular}


The data were collected during the first week of classes to avoid the possibility that the participants' responses on the questionnaires would be influenced by content in the course.

\section{Scoring}

In the first step, once all scores in positive items were added, 78 (weighted value of the midpoint of the scale) was than added to the total score. In the second step all scores in negative items were summed up. In the final stage the values of the first step was substructed the value of second step. These scores show us, one students' evaluation of the teacher.

\section{Findings}

According to independent sample T-Test scores there is no significant differences between males and females' evaluation about teachers' nonverbal immediacy behavior

Table 2. Means and Standard Deviations By Sex

\begin{tabular}{llll}
\hline Sex & N & M & SD \\
\hline Male & 107 & 89,1 & 19,8 \\
Female & 76 & 94,6 & 19,7 \\
\hline Total & 185 & & \\
\hline
\end{tabular}

According to the results, \% 11.4 of the students think that their teachers show low level nonverbal immediacy behaviors. \% 32.4 of the students think that their teachers show medium level nonverbal immediacy behaviors. $\% 56.2$ of the students think that their teachers show high level nonverbal immediacy behaviors. Total mean score $(M=91.3)$ indicates that communication students are finding adequate teachers' nonverbal immediacy behaviors.

Table 3. Mean Score of All Participants

\begin{tabular}{|c|c|c|c|c|}
\hline Never & Rarely & Occasionally & Often & Very Often \\
\hline 1 & 2 & 3 & 4 & 5 \\
\hline 26 & 52 & 78 & 104 & 130 \\
\hline
\end{tabular}




\section{Conclusion}

Establishing and sustaining a good climate in traditional learning environment is an important issue to consider. Communicating through immediate behaviors, teachers establish a positive relationship with students and create a positive environment in class, which translates as students being more interested and motivated and learning more effectively. For this reason, teacher immediacy behaviors are needed to be investigated and instructors' awareness about immediacy behaviors should be raised. Literature suggests that teacher immediacy results in higher levels of affect for the teacher and the content of the course, higher levels of cognitive learning, student motivation and teacher-student interaction, lower levels of resistance to the teacher, classroom anxiety and status differences between teachers and students, higher perceptions of teacher's clarity, credibility and competence and higher evaluations from students and supervisors (Richmond, 2002). When we look at the general results of this study, we can say that communication students are finding adequate teachers' nonverbal immediacy behaviors and there are no differences between males and females level of evaluation. 


\section{References}

Akkuzu, N., \& Akkaya, N. (2014). Development and validity-reliability study of communication skills scale for student teachers: Suggestion of an alternative model. Turkish Studies - International Periodical For The Languages, Literature and History of Turkish or Turkic, 9/8, 111-132.

Andersen, J. F. (1979). Teacher immediacy as a predictor of teaching effectiveness. Communication Yearbook, 3, 543-559.

Argon, T., \& Zafer, D. (2009). İlköğretim okulu yöneticilerinin iletişim sürecinde yaşadıkları problemler: Nitel bir çalışma. The Journal of SAU Education Faculty, 18, 99-123.

Ballester, E.P. (2015). Verbal and nonverbal teacher immediacy and foreign language anxiety in an EFL university course. Porta Linguarum, 23, 9-24. ISSN: 1697-7467

Basaran, M., \& Erdem, I. (2009). Öğretmen adaylarının güzel konuşma becerisi ile ilgili görüşleri üzerine bir araştırma. Kastamonu Eğitim Dergisi, 17(3), 743-754.

Christophel, D. M. (1990). The relationships among teacher immediacy behaviours, student motivation, and learning. Communication Education, 37, 323-340.

Çetinkanat, C. (1997). Öğretmenlerin iletişim becerileri. Paper presented at the 3thInternational Elementary Teaching Semposium, Adana-Turkey: Çukurova University.

Frymier, A. B., \& Houser, M. L. (2000). The teacher-student relationship as an interpersonal relationship. Communication Education, 49, 207-219.

Gorham, J. (1988). The relationship between verbal teacher immediacy behaviors and student learning. Communication Education, 37, 40-53 șepe

Hazneci, Y. (2012). Oluşturmacı öğretmen iletişim beceri ölçeğinin geliştirilmesi ve ilköğretim öğretmenlerinin sınıf içi iletişim becerilerinin incelenmesi. Yayınlanmamış Doktora Tezi. İstanbul: Marmara Üniversitesi.

Hsu, L. (2010). The impact of perceived teachers' nonverbal immediacy on students' motivation for learning English. Asian EFL Journal, (12), 4, 1-17.

Karagöz, Y., \& Kösterelioğlu, I. (2008). İletişim becerileri değerlendirme ölçeğinin faktör analizi metodu ile geliştirilmesi. Dumlupınar Üniversitesi Sosyal Bilimler Dergisi, 21, 81-98.

Küçük, M, \& İspir, B. (2016). Sözsüz yakınlık davranışları sormacasının türkçe versiyonu için geçerlik ve güvenirlik çalışması (Yayınlanmamış Metin - Unpublished manuscript). Anadolu Üniversitesi. 
McCroskey, J. C., Richmond, V. P., \& McCroskey, L. L. (2005). An introduction to communication in the classroom: The role of communication in teaching and training. Boston: Pearson.

Plax, T. G., Kearney, P., McCroskey, J. C., \& Richmond, V. P. (1986). Power in the classroom VI: Verbal control strategies, nonverbal immediacy, and affective learning. Communication Education, 35, 43-55.

Pogue, L. L., \& AhYun, K. (2006). The effect of teacher nonverbal immediacy and credibility on student motivation and affective learning. Communication Education, (55), 3, 331-344.

Richmond, V. P. (2002). Teaching nonverbal immediacy, in J. L. Chesebro (ed.), Communication for teachers. Boston, MA: Allyn and Bacon, 65-82.

Richmond, V. P., Gorham, J. S., \& McCroskey, J. C. (1987). The relationship between selected immediacy behaviors and cognitive learning. In M. L. McLaughlin (ed.), Communication yearbook 10. Newbury Park, CA: Sage, 574-590.

Richmond, V. P., \& McCroskey, J. C. (2000). Nonverbal behavior in interpersonal relationships. Boston, MA: Allyn and Bacon.

Richmond; V.P., McCroskey, J.C., \& Johnson, A.D. (2003). Development of the nonverbal immediacy scale (NIS): Measures of self and other perceived nonverbal immediach. Communication Quarterly, 51 (4), 504-517.

Richmond, V. P., McCroskey, I. C., Kearney, P. \& Plax, T. G. (1987). Power in the classroom VII: Linking behavior alteration techniques to cognitive learning. Communication Education, 36: 1-12.

Rodriguez, J. I., Plax, T. G., \& Kearney, P. (1996). Clarifying the relationship between teacher nonverbal immediacy and student cognitive learning: Affective learning as the central causal mediator. Communication Education, 45, 293-305.

Tarhan, U. (2000). Effect of interpersonel skills training on teachers communication skills and self awareness. PhD dissertation. Ankara: The Middle East Technical University.

Witt, P.L., Schrodt, P., Wheeless, V.E., \& Bryand, M.C. (2014). Students' intent to persist in college: Moderating the negative effects of receiver apprehension with instructor credibility and nonverbal immediacy. Communication Studies, 65 (3), 330-352. 